\title{
Identification of Chemical Content of Fruit and Peel's Extract of Some Varieties' of Pomegranate (Punica granatum L.)
}

\author{
Farogat Sh. Ergasheva ${ }^{1}{ }^{*}$, Khabibjon Kh. Kushiev ${ }^{1}$, Alimjan D. Matchanov ${ }^{2}$, \\ Uchkun J. Ishimov ${ }^{2}$, Khushmatov S. Shunkor ${ }^{3}$ and Pozilov K. Mamirjon ${ }^{3}$ \\ ${ }^{1}$ The Faculty of Natural Sciences of Gulistan State University, Gulistan city, \\ Republic of Uzbekistan \\ ${ }^{2}$ Institute of Bioorganic Chemistry of Academy of Science of Republic of Uzbekistan, ${ }^{3}$ Institute \\ of Biophysics and Biochemistry of National University of Uzbekistan, Tashkent city, \\ Republic of Uzbekistan \\ *Corresponding author
}

\begin{abstract}
A B S T R A C T
Keywords

Pomegranate, Extract, The fruit peel, Vitamins, Macroelements, Microelements

Article Info

Accepted: 10 April 2019 Available Online: 10 May 2019

The goal of this research work is analysis of chemical compounds of extract of fruit and peel of some local varieties pomegranate ("Qora qayim", "Qizil anor", "Oq dona/Tuyatish", "Achchik dona"). The experiments were carried out by using methods of standard chemical synthesis. In the ethanol extract $(70 \%)$ of the fruit peel of varieties "Qora qayim", "Qizil anor", "Oq dona/Tuyatish", "Achchik dona"were identified vitamins A $(0.015-0.063 \mathrm{mg} / 100 \mathrm{ml}), B_{1}(0.034-0.064 \mathrm{mg} / 100 \mathrm{ml}), \mathrm{B}_{2}(0.024-0.052 \mathrm{mg} / 100 \mathrm{ml})$, $\mathrm{B}_{5}(0.023-0.038 \mathrm{mg} / 100 \mathrm{ml}), \mathrm{B}_{6}(0.025-0.082 \mathrm{mg} / 100 \mathrm{ml}), \mathrm{C}(4.805-11.546 \mathrm{mg} / 100 \mathrm{ml})$, and $\mathrm{E}(0.014-0.612 \mathrm{mg} / 100 \mathrm{ml})$, as well as macronutrients $(\mathrm{K}, \mathrm{Ca}, \mathrm{Mg}, \mathrm{Na})$ and micronutrients $(\mathrm{Mn}, \mathrm{Zn}, \mathrm{Cu}, \mathrm{Se})$. The results show that the rind of pomegranate fruits (Punica L.) is a polycomplex property by chemical composition and a promising agent in the development of pharmacological drugs.
\end{abstract}

\section{Introduction}

Pomegranate fruits have been widely used in ancient plants as a source of nutritional value. Pomegranate fruits are attracted by researchers' interest as they are rich for biologically active compounds, microelements and vitamins. The products obtained from the processing of pomegranate fruits are widely used in various juices, meat and fish processing products, pharmacology, and other medicinal products (Cowan, 1999; Dahanukar et al., 2000; Das et al., 2009; Radhika et al., 2011).

Although the pomegranate fruit has been used in the treatment of some internal diseases and skin rashes in folk medicine, the seeds and 
sheaths remain as residuals (Kovalevskaya et al., 2015). Pomegranate fruit contains $85.4 \%$ of water, $10.6 \%$ of total sugar, $1.4 \%$ of pectin and $0.2-1 \%$ of polyphenol compounds (Prakash and Prakash, 2011).

Pomegranate juice is rich with $85.4 \%$ of water, $1.4 \%$ of pectin, $0.2-1 \%$ of polyphenol compounds, and $10.6 \%$ of carbohydrates, while the sheath is rich with citric acid and colorful dubile substances (Prakash and Prakash, 2011). Also, the sheath of pomegranate is rich for pectin composition. Pomegranate seeds contain a large amount of fat, about $67 \%$ of which are unsaturated fatty acids, of which $40 \%$ are linoleic acid. The pomegranate seeds are rich in tocopherol (Gafizov and Semochkina, 1995; Ferrari et al., 2010; Vroegrijk et al., 2011; Afshar et al., 2011; Prakash and Prakash, 2011; Valero et al., 2014; Basiri, 2015; Gafizov, 2015; Kovalevskaya et al., 2015).

It is worthwhile to note that based on the analysis of literature on the pomegranate's chemical composition, the amount of organic and inorganic substances in the juice, seed and crust of pomegranate fruits depends on the region and soil-climatic conditions.

The results obtained in connection with a wide range of physiologically active substances in the juice of pomegranate, peel's and seeds (Aviram et al., 2006; Sreekumar et al., 2014; Akhavan and Barzegar, 2017; Qamar Abbas et al., 2018) show that broader and deeper research is still needed.

Based on the above-mentioned opinions, it is important to study some of the varieties of pomegranate (Punica granatum L.) fruits and peel's chemical compounds vegetated in the Mirzachul oasis, which occupies a large area in the Central Asian region, and the fruits and peel's. Therefore, the purpose of this research was to compare the varieties of certain pomegranate varieties' (Punica granatum L.) produced in the Mirzachul oasis and the amount of vitamins and macromicroelements contained in the fruit and peel's.

\section{Materials and Methods}

In the researches, some of the local varieties of pomegranate (Punica L.) ("Qora qayim", "Qizil anor", "Oq dona/Tuyatish", "Achik dona") cultivated in Syrdarya region of the Mirzachul oasis of Uzbekistan were selected as the object.

Extraction and analysis of ethanol (70\%) extract from the fruit and sheath of pomegranate (Punica L.) varieties is carried out jointly with the staff of the Laboratory of chemistry of lower molecular compounds at the Institute of Bioorganic chemistry.

High-performance liquid chromatography (HPLC) method of determining the vitamin D group (thiamin $-\mathrm{B}_{1}$, riboflavin $-\mathrm{B}_{2}$, pyrotoxin $-\mathrm{B}_{6}$, pantothenic acid $-\mathrm{B}_{5}$, biotin, cyanocobalamin $-\mathrm{B}_{12}$, folic acid) has been reported that it is possible to obtain reliable results (Amidzic et al., 2005; Aslam et al., 2008; Sami et al., 2014).

In the experiments, the method of identification of vitamins within the ethanol (70\%) extract of native varieties of pomegranate (Punica anata L.) was carried out by using the standard method, published in the literature (Ellekr et al., 2004).

This method (high accuracy: $p<0.05$ ) was based on the extraction of vitamins in an organic solvent medium and concentration of extracted extracts in the chromatographic method by fractionation of $\mathrm{C} 18$ in the method of HPLC and at the next stage, analysis of fractions by fluorescence and spectrophotometric detectors found. The 
detection of each individual substance in the content of the test sample contained in the test sample was determined by comparing the detection in the chromatographic system to the standard sample size and area of the "peaks" corresponding to the wavelength (Ellekr et al., 2004; Rowayshed et al., 2013). Experiments were carried out by using Agilent (USA) high-performance liquid chromatography equipment equipped with autosampler "Agilent Technologies-1200" (Fig. 1).

The sequence of methodologies for quantitative analysis of vitamins in HPLC is described in detail in the following manual (Ellekr et al., 2004).

In the experiments, vitamins belonging to group B were determined by standard methods (Aslam et al., 2008; Ringling and Rychlik, 2013).

The pomegranate (Punica L.) extract was powdered and dissolved in $80 \mathrm{mg}$ of $5 \mathrm{ml}$ of 0.1 normal $\mathrm{H}_{2} \mathrm{SO}_{4}$ solutions and stored at $+25^{\circ} \mathrm{C}$ for 100 minutes. In the next step, using sodium acetate, $p H=2.5$ was filtered and prepared in $5 \mathrm{ml}$ test sample in distilled water. Standard vitamin specimens were prepared using the appropriate methods to compare (Aslam et al., 2008; Ringling and Rychlik, 2013).

Chromatographic process at $+25^{\circ} \mathrm{C}, \mathrm{HPLC}-$ based diode matrix (DAD) detector for firm "Agilent Technologies-1200" (USA) was performed on high-performance liquid chromatography device. Chromatography conditions: column type - Eclipse XDB C18; the length of the column is $150 \times 4,6 \mathrm{~mm}$; sorbent volume -5 micrometer; flow rate -1 $\mathrm{ml} / \mathrm{min}$. Melting system: A: acetonitrile; B: Acetate buffer (rN-3.0-3.5). Chromatography conditions gradient \% A/min: 0-2\%/0-4 min; 2-20\%/4.1-8 $\mathrm{min} ; \quad 20-0 \% / 8.1-10 \mathrm{~min}$.
Detection wavelengths - $204 \mathrm{~nm}, 245 \mathrm{~nm}$, $254 \mathrm{~nm}, 290 \mathrm{~nm}$ and $325 \mathrm{~nm}$.

The vitamins $\mathrm{A}$ and $\mathrm{E}$ were found to be 325 $\mathrm{nm}$ and $290 \mathrm{~nm}$ respectively, according to the standard method (Sami et al., 2014).

Determination of macronutrients and micronutrients content of pomegranate (Punica granatum L.) fruits and peel's

In experiments, the pomegranate (Punica granatum L.) fruit and inductively coupled argon plasma were analyzed by Massspectrometry method (ISP-MC NEXION2000, Perkin Elmer USA) (Rowayshed et al., 2013).

The samples were sampled on an analytical scale and placed in autoclave with teflon and the acids breakdown method was used. The shredding works were performed for $35 \mathrm{~min}$ at the "Berghof" microwave breaking device (Germany) with MWS-3 + software. The tube was transferred to the measuring tubes as the amount of the resulting solution. Mass spectrometer was analyzed for autosampler analysis. The analysis was based on the multielement standard. The standard concentration of calibration was at concentrations of $10 \mathrm{mg} / \mathrm{l}(10 \mathrm{ppb})$ and 100 $\mathrm{mg} / \mathrm{l}$ (100 ppb). Conditions of analysis: generator (plasma) voltage $-1500 \mathrm{~W}$; flow speed - $0.7 \mathrm{ml} / \mathrm{min}$; nebulizer - $0.8 \mathrm{l} / \mathrm{min}$.; argon (plasma) - 15 1/min.

\section{Solvents and chemicals}

In the experiments were used methanol, acetonitrile ("Sigma-Aldrich", Germany) for the liquid chromatography technique (mobile phase). Standardized samples were used as standard vitamins (retinol acetate $\left(\mathrm{C}_{22} \mathrm{H}_{32} \mathrm{O}_{2}\right)$, $\alpha$-tocopherol acetate $\left(\mathrm{C}_{31} \mathrm{H}_{52} \mathrm{O}_{2}\right)$, pyridoxine hydrochloride, riboflavin, thiamine, ascorbic acid, etc. ("Sigma-Aldrich", Germany). 


\section{Data analysis}

The results were statistically processed by a special software package OriginPro v. 8.5 SR1 (EULA, USA). The results of experiments processed mathematicallystatistically using standard biometric methods (Lakin, 1990).

\section{Results and Discussion}

The sheath and fruits of the first varieties of pomegranate were separated and mechanically mixed in sterile conditions. The weighted samples weight $(5-10 \mathrm{~g})$ were measured ("CAS_CUW220H"; China, the accuracy was $0.01 \mathrm{~g})$ and the tubes $(\mathrm{V}=300$ $\mathrm{ml}$ ) were added and $50 \mathrm{ml}$ of ethanol solution $(70 \%)$ was added. Tubular magnetic fridge (Russia) $60 \mathrm{~min}$. It was stored at $+110{ }^{\circ} \mathrm{C}$ under temperature conditions. In the next step the mixture was extracted 2 times in $25 \mathrm{ml}$ of ethanol solution $(70 \%)$. The filtrate was dissolved in $100 \mathrm{ml}$ of ethanol (40\%) and was incubated for $10 \mathrm{~min}$ at $7000 \mathrm{rpm}$. during centrifugation. The deposition was removed and the resulting solution was used as a porcine extract in the next chemical analysis (Fig. 2).

\section{Analysis of quantity of vitamins}

In the experiments, the following results were obtained in the Mirzachul oasis of the Republic of Uzbekistan, as a result of the HPLC analysis of some of the pomegranate varieties grown in Syrdarya region ("Qora qayim", "Qizil anor", "Oq dona/Tuyatish", "Achik dona") (Fig. 3; Table 1).

Pomegranate (Punica granatum L.) contains vitamins of $A(0.164 \mathrm{mg} / 100 \mathrm{~g})$, vitamin $\mathrm{B}_{1}$ $(0.123 \mathrm{mg} / 100 \mathrm{~g})$, vitamin $\mathrm{B}_{2}(0.07 \mathrm{mg} / 100$ g), Vitamin C (12.9 mg/100 g), vitamin E $(3.99 \mathrm{mg} / 100 \mathrm{~g})$ that many other researchers have reported (Ellekr et al., 2004).
In addition, using HPFC method, juice of varieties of pomegranate includes vitamin $\mathrm{A}$ (44-236.1 mg/100 ml), vitamin $\mathrm{B}_{1}(30.8-$ $124.1 \mathrm{mg} / 100 \mathrm{ml})$, vitamin $\mathrm{B}_{5}(114.9-301.5$ $\mathrm{mg} / 100 \mathrm{ml})$, vitamin $\mathrm{B}_{6}(12-90.3 \mathrm{mg} / 100 \mathrm{ml})$ was found to be vitamin $\mathrm{C}(10.4-35.4 \mathrm{mg} / 100$ ml) (Akhavan and Barzegar, 2017). In the next series of experiments, the yield of local varieties of pomegranate varieties and macroelements and microelements in the sheath was analyzed as well (Table 2).

It is necessary to mention that during the conducted researches in the content of pomegranate peel's (Punica Granatum L.) there were determined the followings $\mathrm{Ca}$ (338.5 mg/100 g), K (146.6 mg/100 g), Na $(66.43 \mathrm{mg} / 100 \mathrm{~g}), \mathrm{P}(117.9 \mathrm{mg} / 100 \mathrm{~g}), \mathrm{Fe}$ $(5.93 \mathrm{mg} / 100 \mathrm{~g}), \mathrm{Zn}(1.01 \mathrm{mg} / 100 \mathrm{~g}), \mathrm{Mn}(0.8$ $\mathrm{mg} / 100 \mathrm{~g}), \mathrm{Cu}(0.6 \mathrm{mg} / 100 \mathrm{~g})$, Se $(1.03$ $\mathrm{mg} / 100 \mathrm{~g}$ ) (Rowayshed et al., 2013).

When analyzing the chemical composition of 23 types of commercial fruit juices by some researchers, K (209.3-251.7 mg/100 ml), P (9.3-15.1 mg/100 ml), Ca (1.1-14.9 mg/100 $\mathrm{ml}), \mathrm{Mg}(2.1-10.4 \mathrm{mg} / 100 \mathrm{ml})$ and $\mathrm{Na}(2-$ $12.8 \mathrm{mg} / 100 \mathrm{ml}$ ) were found (Eksi and Ozhamamci, 2009).

Also, the concentration of the chemical elements contained in the pomegranate plant ( $\mathrm{Zn}, \mathrm{Mn}, \mathrm{Cu}, \mathrm{Fe}, \mathrm{K}$, etc.) is also related to plant growth conditions, agrochemical processing (Hasani et al., 2012; Hamouda et al., 2016; Korkmaz et al., 2017).

In particular, the concentration of polyphenols, macroelements $(\mathrm{P}, \mathrm{K}, \mathrm{Mg}, \mathrm{Ca}$, $\mathrm{Na})$ and micronutrients $(\mathrm{Zn}, \mathrm{Cu}, \mathrm{Mn}, \mathrm{Fe})$ in the sheath of pomegranate (Punica granatum L.) has significantly changed during the ripening of the fruit (Parashar et al., 2014).

Thus, it was determined that the concentration of macroelements $\mathrm{K}>\mathrm{Ca}>\mathrm{P}>\mathrm{Mg}>\mathrm{Na}$ and 
microelements concentration $\mathrm{Fe}>\mathrm{Zn}>\mathrm{Cu}>\mathrm{Mn}$ has the sequence in the fruiting field (Parashar et al., 2014) (Table 3).

Particularly, the pomegranate (Punica granatum L.) contains a large amount of vitamin $\mathrm{C}$, which has a broad spectrum of vegetation-dependent geographical areas, as well as the age of fruit ripening (Kulkarni et al., 2005). In particular, in the research, pomegranate fruits grown in different geographical regions contain 9.91-20.92 $\mathrm{mg} / 100 \mathrm{ml}$ (Tehranifar et al., 2010), 312$1050 \mathrm{mg} / 100 \mathrm{mg}$ (Dumlu and Gürkan, 2007), $52.8-72 \mathrm{mg} / 100 \mathrm{ml}$ (Opara et al., 2009).

The difference between the values of quantitative data presented in literature and the results obtained in experiments can be explained by the geographical region, varieties and harvesting periods of plant varieties (Punica granatum L.).

Table.1 The amount of vitamins in the fruit and sheath varieties of pomegranate $(\mathrm{mg} / 100 \mathrm{ml})$

\begin{tabular}{|c|c|c|c|c|c|c|c|c|c|}
\hline \multirow[t]{2}{*}{$\#$} & \multirow{2}{*}{\multicolumn{2}{|c|}{ Pomegranate varieties }} & \multicolumn{7}{|c|}{ Vitamins } \\
\hline & & & $\mathbf{A}$ & $\mathbf{B}_{1}$ & $\mathbf{B}_{2}$ & $B_{5}$ & $B_{6}$ & C & $\mathbf{E}$ \\
\hline \multirow[t]{2}{*}{1} & \multirow{2}{*}{ "Qora qayim" } & Peel's & 0.015 & 0.034 & 0.052 & 0.031 & 0.045 & 11.546 & 0.037 \\
\hline & & Fruit & 0.164 & 0.053 & 0.068 & 0.035 & 0.085 & 12.345 & 0.054 \\
\hline \multirow[t]{2}{*}{2} & \multirow[t]{2}{*}{ "Qizil Anor" } & Peel's & 0.04 & 0.032 & 0.033 & 0.025 & 0.032 & 8.330 & 0.014 \\
\hline & & Fruit & 0.143 & 0.084 & 0.036 & 0.041 & 0.081 & 13.635 & 0.645 \\
\hline \multirow[t]{2}{*}{3} & \multirow{2}{*}{$\begin{array}{l}\text { "Oq } \\
\text { dona/Tuyatish" }\end{array}$} & Peel's & 0.056 & 0.052 & 0.024 & 0.032 & 0.059 & 4.805 & 0.036 \\
\hline & & Fruit & 0.132 & 0.069 & 0.048 & 0.036 & 0.074 & 7.092 & 0.547 \\
\hline \multirow[t]{2}{*}{4} & \multirow[t]{2}{*}{ "Achik dona" } & Peel's & 0.063 & 0.064 & 0.042 & 0.023 & 0.025 & 8.412 & 0.025 \\
\hline & & Fruit & 0.157 & 0.072 & 0.054 & 0.038 & 0.082 & 14.236 & 0.612 \\
\hline
\end{tabular}

Table.2 The amount of macro elements contained in fruit and sheath of pomegranate varieties $(\mathrm{mg} / 100 \mathrm{ml})$

\begin{tabular}{|c|c|c|c|c|c|c|c|}
\hline \multirow[t]{2}{*}{ \# } & \multirow{2}{*}{\multicolumn{2}{|c|}{ Pomegranate varieties }} & \multicolumn{5}{|c|}{ Macroelements } \\
\hline & & & $K$ & $\mathrm{Ca}$ & $M g$ & $\mathrm{Na}$ & $P$ \\
\hline \multirow[t]{2}{*}{1} & \multirow[t]{2}{*}{ "Qora qayim" } & Peel's & 0.783 & 0.438 & 0.115 & 0.340 & 0.341 \\
\hline & & Fruit & 226.128 & 8.457 & 12.184 & 3.237 & 32.295 \\
\hline \multirow[t]{2}{*}{2} & \multirow[t]{2}{*}{ "Qizil Anor" } & Peel's & 0.432 & 0.356 & 0.196 & 0.567 & 0.428 \\
\hline & & Fruit & 198.639 & 11.345 & 11.385 & 5.986 & 29.322 \\
\hline \multirow[t]{2}{*}{3} & \multirow[t]{2}{*}{ "Oq dona/Tuyatish" } & Peel's & 0.543 & 0.521 & 0.783 & 0.823 & 0.277 \\
\hline & & Fruit & 213.541 & 9.134 & 11.234 & 4.257 & 35.273 \\
\hline \multirow[t]{2}{*}{4} & \multirow[t]{2}{*}{ "Achchik dona" } & Peel's & 0.674 & 0.670 & 0.234 & 0.451 & 0.450 \\
\hline & & Fruit & 265.465 & 10.283 & 13.254 & 6.672 & 36.349 \\
\hline
\end{tabular}

Table.3 Amount of microelements in the fruit and sheath of pomegranate varieties (mg/100 ml)

\begin{tabular}{|c|c|c|c|c|c|c|c|}
\hline \multirow[t]{2}{*}{ \# } & \multicolumn{2}{|c|}{ Pomegranate varieties } & \multicolumn{5}{|c|}{ Microelements } \\
\hline & & & $\mathrm{Fe}$ & $M n$ & $Z n$ & $\mathrm{Cu}$ & $\mathrm{Se}$ \\
\hline \multirow[t]{2}{*}{1} & \multirow[t]{2}{*}{ "Qora qayim" } & Peel's & 0.035 & 0.086 & 0.024 & 0.013 & 0.034 \\
\hline & & Fruit & 0.597 & 0.123 & 0.314 & 0.163 & 0.656 \\
\hline \multirow[t]{2}{*}{2} & \multirow[t]{2}{*}{ "Qizil anor" } & Peel's & 0.047 & 0.084 & 0.039 & 0.023 & 0.017 \\
\hline & & Fruit & 0.386 & 0.129 & 0.428 & 0.158 & 0.543 \\
\hline \multirow[t]{2}{*}{3} & \multirow[t]{2}{*}{ "Oq dona/Tuyatish" } & Peel's & 0.086 & 0.075 & 0.042 & 0.074 & 0.058 \\
\hline & & Fruit & 0.219 & 0.126 & 0.510 & 0.164 & 0.498 \\
\hline \multirow[t]{2}{*}{4} & \multirow[t]{2}{*}{ "Achchik dona" } & Peel's & 0.054 & 0.092 & 0.049 & 0.028 & 0.076 \\
\hline & & Fruit & 0.442 & 0.118 & 0.476 & 0.162 & 0.585 \\
\hline
\end{tabular}


Fig.1 Determination of vitamins in ethanol (50\%) extract of native varieties of pomegranate (Punica L.) in HPFC method

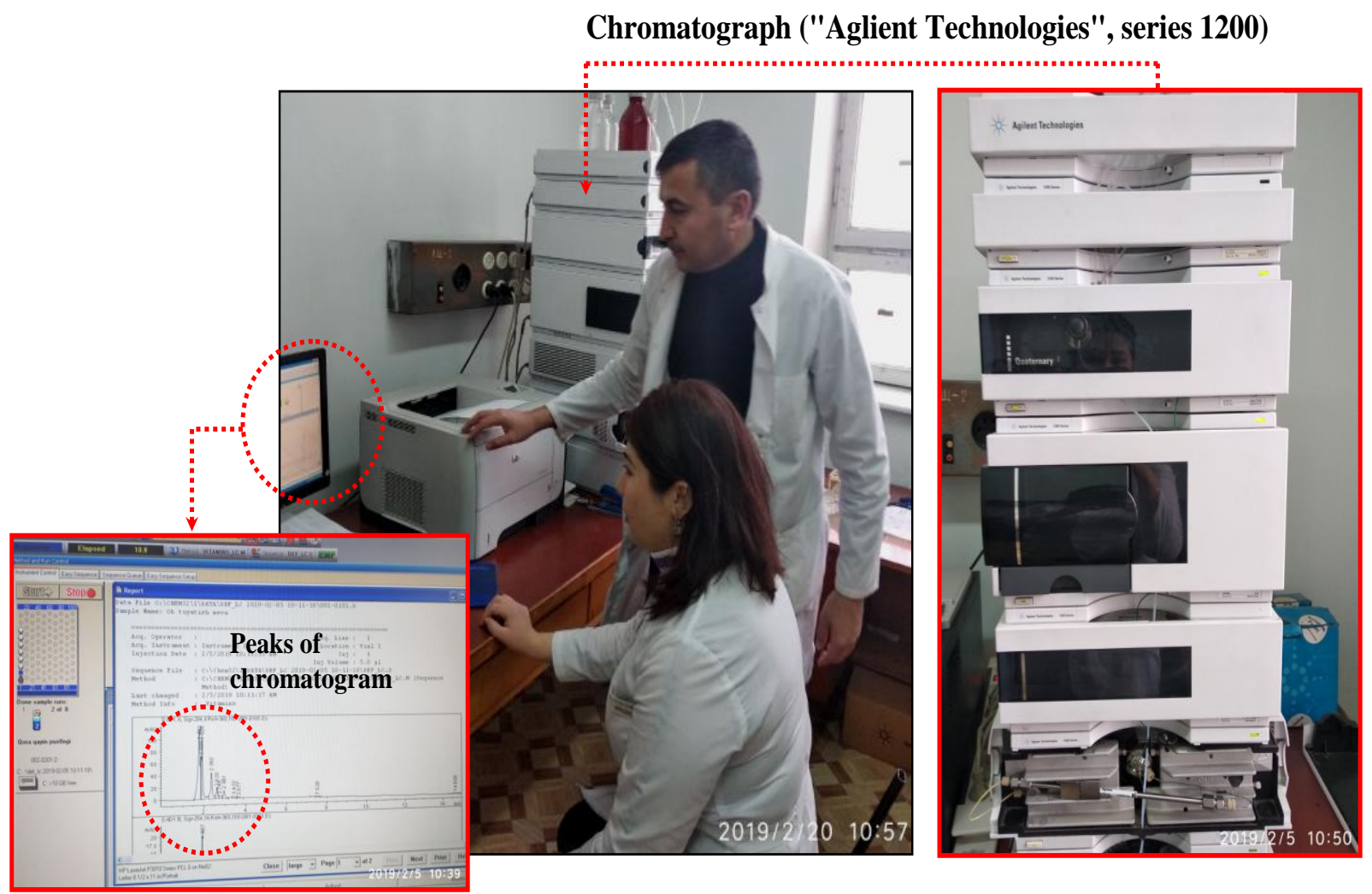

Interface of automatic record supplied with special software

Fig.2 Process of preparation of ethanol extract of Pomegranate (Punica granatum L.) fruit and peel's

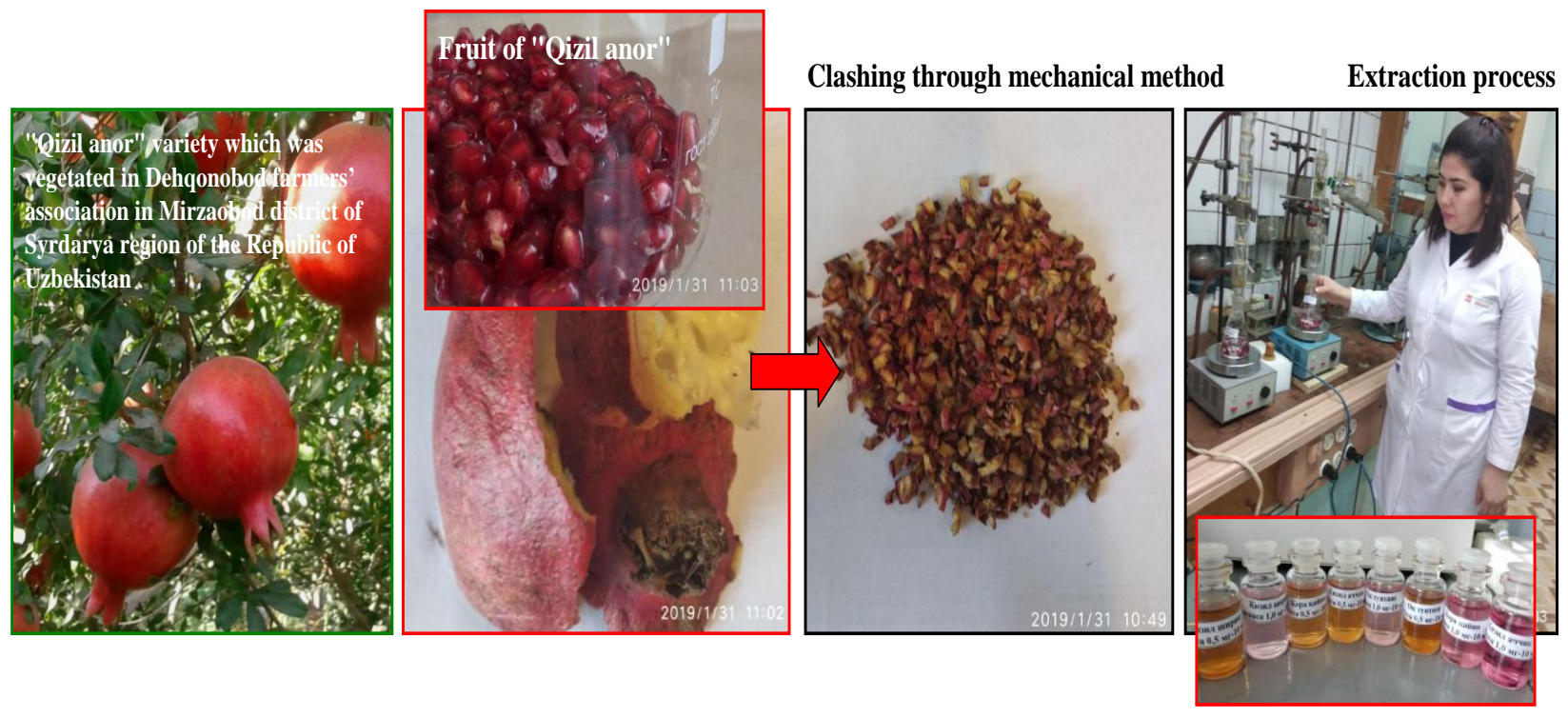


Fig.3 Chromatogram of pomegranate extract

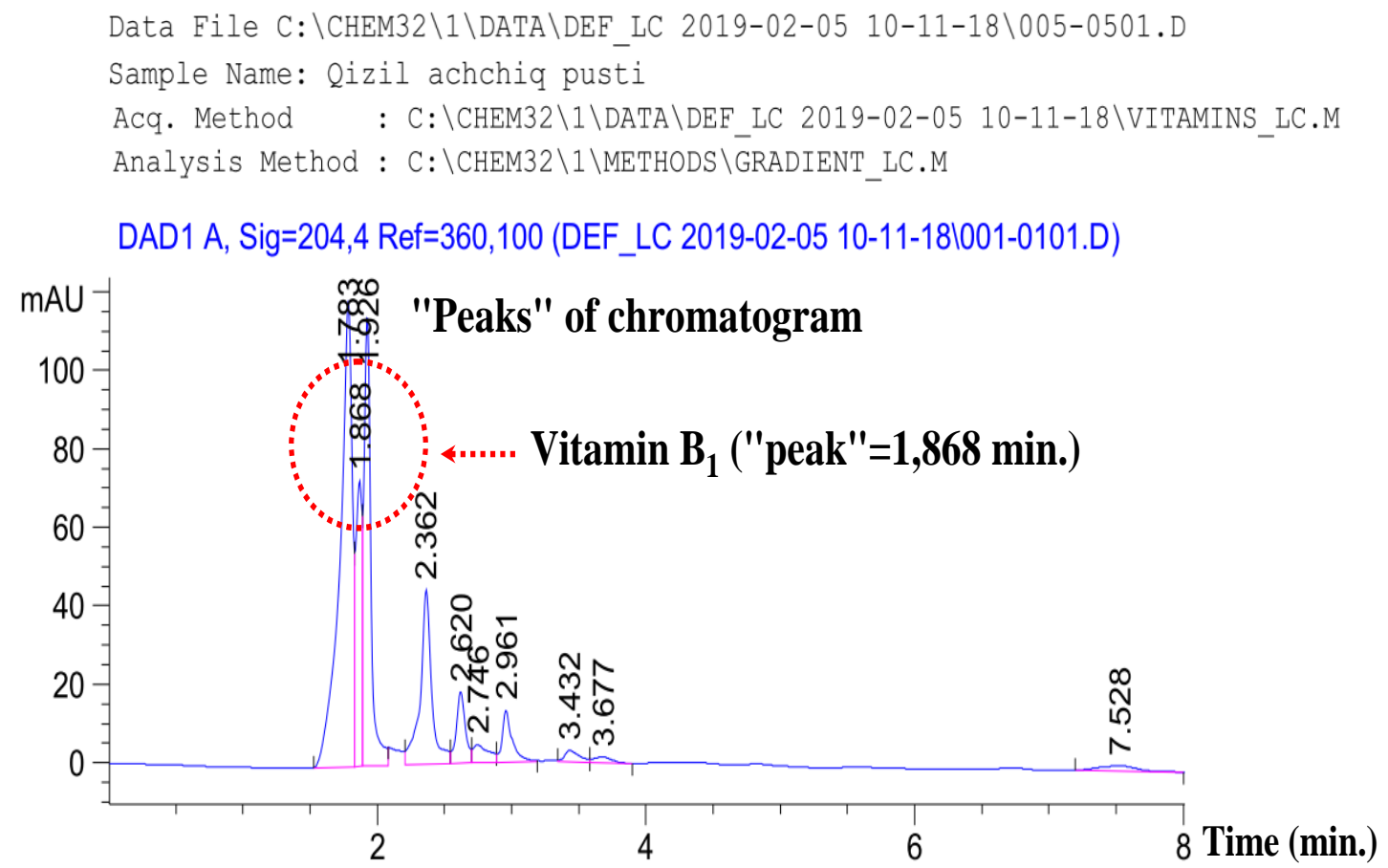

In conclusion, in this research, the Mirzachul oasis of the Republic of Uzbekistan has been acknowledged as a pomegranate produced in Syrdarya region by the varieties of "Qora qayim", "Qizil anor", "Oq dona/Tuyatish", and "Achchiq Dona" varieties of vitamins (A, $\mathrm{B}, \mathrm{C}, \mathrm{E})$, as well as macroelements $(\mathrm{K}, \mathrm{Ca}$, $\mathrm{Mg}, \mathrm{Na}, \mathrm{R}$ ) and microelements (Fe, $\mathrm{Mn}, \mathrm{Zn}$, $\mathrm{Cu}, \mathrm{Se})$.

The obtained results can be used as a scientific basis for the analysis of the chemical composition and pharmacological activity of pomegranate (Punica granatum L.) extract.

\section{Acknowledgement}

The research was carried out and funded within the framework of the project $\mathrm{S}-\mathrm{A}-$ 2018-004 "Establishment of biotechnological collection of pomegranate (Punica granatum L.)", which has been implemented at Gulistan State University (Republic of Uzbekistan).

\section{References}

Afshar M.-A., Naser M.-S., Hormor M. et.al. 2011. Evaluting potentional nutritive value of pomegranate processing byproducts for ruminants using in vitro gas production technique //ARPN $\mathrm{J}$ of Agricultural and Biological Science. 6(6): $1-7$.

Akhavan, H.R., Barzegar, M. 2017. Determination of water-soluble vitamins in 15 Iranian pomegranate cultivars and their variation after pasteurization and cold storage. International Food Research Journal. 24(4): 1429-1436.

Amidzic, R., Brboric, J., Cudina, O., Vladimirov, S. 2005. RP-HPLC determination of vitamins $\mathrm{B}_{1}, \mathrm{~B}_{3}, \mathrm{~B}_{6}$, folic acid and $\mathrm{B}_{12}$ in multivitamin tablets. Journal of the Serbian Chemical Society. 70(10): 1229-1235.

Aslam, J., Mohajir, M.S., Khan, S.A., Khan, A.Q. 2008. HPLC analysis of watersoluble vitamins $\left(\mathrm{B} 1, \mathrm{~B}_{2}, \mathrm{~B}_{3}, \mathrm{~B}_{5}, \mathrm{~B}_{6}\right)$ in in vitro and ex vitro germinated chickpea 
(Cicer arietinum L.). African Journal of Biotechnology. 7(14): 2310-2314.

Aviram, M., Rosenblat, M., Volkova, N., Coleman, R. 2006. Pomegranate by product administration to apolipoprotein e-definicient mice attenuates atherosclerosis development as a result of decreased macrophage oxidative stress and reduced cellular uptake of oxidized low-density lipoprotein. J. Agr. Food. Chem. 54: 1928-1935.

Basiri, S., 2015. Evaluation of antioxidant and antiradical properties of pomegranate (Punica granatum L.) seed and defatted seed extracts. J. Food Sci. Technol. 52: 1117-1123.

Cowan, M.M. 1999. Plant products as antimicrobial agents. Clinical microbiology reviews. 12(4): 564-82.

Dahanukar, S.A., Kulkarni, R.A., Rege, N.N. 2000. Pharmacology of medicinal plants and natural products. Indian Journal of pharmacology. 32(4): S81-118.

Das, S, Sama, G. Antidiabetic Action of Ethanolic Extracts of Punica granatum Linn. in Alloxan-induced Diabetic Albino Rats. Stamford Journal of Pharmaceutical Sciences. 2009. 2(1): 14-21.

Dumlu, M.U., Gürkan, E. 2007. Elemental and nutritional analysis of Punica granatum from Turkey. Journal of Medicinal Food. 10(2): 392-395.

Eksi, A., Ozhamamci, I. 2009. Chemical composition and guide values of Pomegranate juice. GIDA. 34(5): 265270.

Ellekr, K.I., Aleshko-Ojevskiy, Yu.P., Aristarxova, T.V., Baykov, V.G., Beketova, N.A. 2004. i dr. Rukovodstvo po metodam kontrolya kachestva i bezopasnosti biologicheski aktivnyh dobavok k pishe. Federalnyy sentr gossanepidnadzora Minzdrava Rossii (Moskva): 51-62 (In Russian).

Ferrari, G., Maresca, P., Ciccarone R. 2010. The application of high hydrostatic pressure for the stabilization of functional foods: Pomegranate juice. J. Food Engineering. 100: 245-253.
Gafizov, G.K. 2015. Izuchenie voprosov kompleksnoy pererabotki plodov granata. Proceedings of the International Scientific and Practical Conference "Methodology of modern research". Dubai (Rost Publishing): 15-27 (In Russian).

Gafizov, G.K., Semochkina, L.G. 1995. Sposob kompleksnoy pererabotki korki i peregorodok plodov granata. Patent SSSR \#1733448. Byul. 18 (In Russian).

Hamouda, H.A., Khalifa, R.Kh.M., ElDahshouri, M.F., Zahran, N.G. 2016. Yield, fruit quality and nutrients content of pomegranate leaves and fruit as influenced by iron, manganese and zinc foliar spray. Int. J. Pharm. Tech. Res. 9(3): 46-57.

Hasani, M., Zamani, Z., Savaghebi, G., Fatahi, R. 2012. Effects of zinc and manganese as foliar spray on pomegranate yield, fruit quality and leaf minerals. Journal of Soil Science and Plant Nutrition. 12(3): 471480.

Korkmaz, N., Askin, M.A., Atilla, M. 2017. Effects of $\mathrm{GA}_{3}$, calcium and boron applications to seasonal changes of leaf, peel and aril mineral nutritions on Hicaznar pomegranate (Punica granatum L.). International Journal of Agriculture, Forestry and Life Science. 1(1): 27-51.

Kovalevskaya, A.A., Drozdov, A.N., Gyulushanyan, A.P., Kalmanovich, S.A. 2015. Razrabotka retseptur sladkih nastoek na osnove kojury plodov granata // Nauchnye trudy Kubanskogo gosudarstvennogo texnologicheskogo universiteta. 11: 207-216.

Kovalevskaya, A.A., Kalmanovich, S.A., Drozdov, A.N. 2015. Poroshok iz semyan granata kak texnologicheskifunksionalnaya dobavki pri proizvodstve saxarnogo pechenya. Materialy IV Mejdunarodnoy nauchno-prakticheskoy konferensii "Xlebobulochnye, konditerskie i makaronnye izdeliya XXI veka". Krasnodar: 129-130 (In Russian).

Kulkarni, A.P., Aradhya, S.M. 2005. Chemical changes and antioxidant activity in pomegranate arils during fruit 
development. Food Chemistry. 93(2): 319-324.

Lakin, G.F. 1990. Biometriya (Moskva). Izd-vo "Vysshaya shkola": 23-284 (In Russian).

Opara, L.U., Al-Ani, M.R., Al-Shuaibi, Y.S. 2009. Physico-chemical properties, vitamin $\mathrm{C}$ content, and antimicrobial properties of pomegranate fruit (Punica granatum L.). Food Bioprocess Technology. 2: 315-321.

Parashar, A., Gupta, Sh., Ansari, M.A., Rajawat, A. 2014. Recurring transformation of mineral nutrients and phenolics in pomegranate (Punica granatum L.) fruit. IJMCA. 4(5): 271278.

Prakash, C.V.S., Prakash, I. 2011. Bioactive chemical constituents from pomegranate (Punica granatum) juice, seed and peel-A Review. International Journal of Research in Chemistry and Environment 1: 1-18.

Qamar Abbas, S., Zara, B., Rizwan, S., Tahir, Z. 2018. Nutritional and therapeutic properties of pomegranate. Schol. J. Food \& Nutr. 1(4): 115-120.

Radhika, S., Smila, K.H., Dan Muthezhilan, R. 2011. Antidiabetic and Hypolipidemic Activity of Punica granatum Linn on Alloxan Induced Rats. World Journal of Medical Sciences. 6: 178-82.

Ringling, C., Rychlik M. 2013. Analysis of seven folates in food by LC-MS/MS to improve accuracy of total folate data. European Food Research and Technology. 236: 17-28.

Rowayshed, G., Salama, A., Abul-Fadl, M., Akila-Hamza, S., Mohamed, A. 2013.
Nutritional and chemical evaluation for pomegranate (Punica granatum L.) fruit peel and seeds powders by products. Middle East Journal of Applied Sciences. 3(4): 169-179.

Sami, R., Li, Y., Qi, B., Wang, Sh., Zhang, Q., Han, F., Ma, Y., Jing, J., Jiang, L. 2014. HPLC analysis of water-soluble vitamins $\left(\mathrm{B}_{2}, \mathrm{~B}_{3}, \mathrm{~B}_{6}, \mathrm{~B}_{12}\right.$, and $\left.\mathrm{C}\right)$ and fat-soluble vitamins ( $\mathrm{E}, \mathrm{K}, \mathrm{D}, \mathrm{A}$, and $\beta$-carotene) of okra (Abelmoschus esculentus). Hindawi Publishing Corporation. Journal of Chemistry. 1-6.

Sreekumar, S., Sithul, H., Muraleedharan, P., Azeez, J.M., Sreeharshan, S. 2014. Pomegranate Fruit as a Rich Source of Biologically Active Compounds. Hindawi Publishing Corporation BioMed Research International. 1-12.

Tehranifar, A., Zarei, M., Nemati, Z., Esfandiyari, B., Vazifeshenas, M.R. 2010. Investigation of physico-chemical properties and antioxidant activity of twenty Iranian pomegranate (Punica granatum L.) cultivars. Scientia Horticulturae. 126(2): 180-185.

Valero, M., Vegara, S., Marti, N., Saura, D. 2014. Clarification of pomegranate juice at industrial scale. Food Process Technol. 5(5): 324-329.

Vroegrijk, I.O.C.M., Van Diepen, J.A.S. Van den Berg, et al., 2011. Pomegranate seed oil, a rich source of punicic acid, prevents diet-induced obesity and insulin resistance in mice. Food and Chemical Toxicology. 49(6): 1426-1430.

\section{How to cite this article:}

Farogat Sh. Ergasheva, Khabibjon Kh. Kushiev, Alimjan D. Matchanov, Uchkun J. Ishimov, Khushmatov S. Shunkor and Pozilov K. Mamirjon. 2019. Identification of Chemical Content of Fruit and Peel's Extract of Some Varieties' of Pomegranate (Punica granatum L.). Int.J.Curr.Microbiol.App.Sci. 8(05): 734-742. doi: https://doi.org/10.20546/ijcmas.2019.805.086 